\title{
Sources of acid insoluble ash as marker of corn digestibility in broilers
}

\section{Fontes de cinza insolúvel em ácido como indicador de digestibilidade do milho em frangos de corte}

\author{
Edna Teles dos Santos ${ }^{1}$; Flávio Ferreira da Silva²; Fabrício Coelho Barbosa; \\ Genilson Bezerra de Carvalho4; Leonardo Atta Farias ${ }^{5}$; Daniel Biagiotti6; Roseane \\ Madeira Bezerra ${ }^{7 *}$; Leilane Rocha Barros Dourado ${ }^{8}$
}

\section{Highlights}

AME and DMDC are similar in the two methods of excreta collection using kaolin.

CPDC is similar in the two methods of excreta collection using kaolin and celite.

Sand used with partial excreta collection method provided low AME and CPDC values.

\begin{abstract}
The objective was to evaluate three sources of acid insoluble ash (AIA) (celite, kaolin, and sand), as indicators, to determine the apparent metabolizable energy of corn on a natural matter (AME) basis, dry matter digestibility coefficient (DMDC), and crude protein digestibility coefficient (CPDC) using total and partial excreta collection methods. Two hundred and ten Ross broiler chicks of 18 to 27 days of age were used. Broilers were adapted to experimental the diet for four days, and excreta were collected for 5 days. A reference diet (RD) based on corn and soybean meal was prepared to meet the nutritional requirements of the birds. A test diet was prepared with $40 \%$ replacement of RD with corn. The formulated diets were: D1, 99\% Reference diet + 1\% celite; D2, 59.4\% RD + 39.6 \% corn + 1\% celite; D3, 99\% Reference diet $+1 \%$ kaolin; D4, 59.4\% RD + 39.6 \% corn + 1\% kaolin; D5, 99\% Reference diet + 1\% sand; D6, 59.4\% RD + 39.6 $\%$ corn $+1 \%$ sand. The treatments were distributed in a completely randomized design, with six diets and five replicates of seven birds each in a $2 \times 3$ factorial arrangement. There were significant interactions for

1 Dra in Animal Science, Universidade Federal do Piauí, UFPI, Campus Profa Cinobelina Elvas, Bom Jesus, PI, Brazil. E-mail: edna1906@hotmail.com

2 Veterinarian, UFPI, Campus Profa Cinobelina Elvas, Bom Jesus, PI, Brazil. E-mail: flavioferreira_26@hotmail.com

${ }^{3}$ Master's Degree in Animal Science, UFPI, Campus Profa. Cinobelina Elvas, Bom Jesus, PI, Brazil. E-mail: fabricio.fcb. barbosa@gmail.com

${ }^{4}$ Dr. in Animal Science, UFPI, Campus Profa. Cinobelina Elvas, Bom Jesus, PI, Brazil. E-mail: ge.nilson.bezerra@ hotmail.com

5 Prof. Dr., UFPI, Campus Profa Cinobelina Elvas, Bom Jesus, PI, Brazil. E-mail: leonardoatta@yahoo.com.br

6 Prof. Dr., Colégio Técnico, UFPI, Campus Profa Cinobelina Elvas, Bom Jesus, Pl, Brazil. E-mail: biagiotti@ufpi.edu.br

7 Dra in Animal Nutrition, UFPI, Campus Profa Cinobelina Elvas, Bom Jesus, PI, Brazil. E-mail: roseanemadeira@ hotmail.com

8 Profa Dra, UFPI, Campus Petrônio Portela, Teresina, PI, Brazil. E-mail: leilane@ufpi.edu.br

* Author for correspondence
\end{abstract}

Received: Sept. 09, 2021 - Approved: Nov. 25, 2021 
all variables investigated. It was observed that the AME and DMDC values of corn were similar in the two methods of collection, and CPDC values using kaolin and celite makers were similar. However, the AME and CPDC of corn using sand with partial collection method were underestimated by 17.70 and $15.53 \%$, respectively compared to those with the total collection method. The AME values of corn with the collection methods using celite and, the DMDC using celite and sand were significantly different. It was observed that the DMDC using celite and sand provided significantly lower values (4.67 and 5.15\%), respectively, and the AME using celite was $2.86 \%$ lower than that obtained by total collection. To determine the EMA, DMDC, and CPDC in broilers, it is more efficient to use celiteTM and kaolin as markers with partial collection of excreta. Sand should not be used with partial excreta collection method, because it provides lower values of AME and CPDC compared to with total excreta collection method.

Key words: Kaolin. Metabolizable energy. Sand. Total collection.

\section{Resumo}

Objetivou-se avaliar três fontes de cinza insolúvel em ácido (CIA) (celite, caulim, e areia), como indicadores para determinação da energia metabolizável aparente do milho na matéria natural (EMA), coeficiente de digestibilidade da matéria seca (CDMS), e coeficiente de digestibilidade da proteína bruta (CDPB) por meio dos métodos de coleta total e parcial de excretas. Foram utilizados duzentos e dez frangos da linhagem comercial Ross no período de 18 a 27 dias de idade. Os frangos foram adaptados à dieta experimental por quatro dias, e as excretas foram coletadas por 5 dias. Foi formulada uma dieta referência (DR) a base de milho e farelo de soja para atender as exigências nutricionais das aves. A dieta teste com substituição de $40 \%$ de milho à DR. As dietas formuladas foram: D1, 99\% dieta referência + 1\% celite; D2, 59.4\% DR + $39.6 \%$ milho + 1\% celite; D3, 99\% dieta referência + 1\% caulim; D4, 59.4\% RD + $39.6 \%$ milho + 1\% caulim; D5, 99\% dieta referência + 1\% areia; D6, 59.4\% DR + 39.6\% milho + 1\% areia. Os tratamentos foram distribuídos em delineamento inteiramente casualizado, com seis dietas e cinco repetições de 7 aves cada em esquema fatorial $2 \times 3$. Houve interações significativas para todas as variáveis investigadas. Observouse que os valores de EMA e CDMS do milho são semelhantes pelos dois métodos de coleta utilizando caulim, e CDPB utilizando caulim e celite. Contudo, a EMA e o CDPB do milho usando areia na coleta parcial foram subestimados em 17,70 e 15,53\%, respectivamente, em relação à coleta total. Os valores EMA do milho para os métodos de coleta usando celite e, o CDMS usando celite e areia foram significativamente diferentes. Observou-se que o CDMS com celite e areia proporcionou valores significativamente menores (4,67 e 5,15\%), respectivamente, e a EMA com celite foi $2,86 \%$ menor que o obtido pela coleta total. Para determinar a EMA, CDMS e CDPB em frangos de corte, é mais eficiente usar celiteTM e caulim como indicadores na coleta parcial de excretas. A areia não deve ser usada com o método de coleta parcial de excretas, pois fornece valores menores de EMA e CDPB em comparação com o método de coleta total de excretas.

Palavras-chave: Areia. Caulim. Coleta total. Energia metabolizável. 
Current broilers have high weight gain, owing to high feed intake. Feed represents the largest fraction of production costs in commercial poultry. Energy content is the most expensive component of feed and one of the main factors that limits the performance of poultry animals. An accurate estimate of the energy value of foods is reflected in increases in weight gain and better feed conversion rates (Melo et al., 2014). Thus, it is necessary to accurately analyze the digestibility of nutrients and energy in feed.

The digestibility of nutrients and energy in diets indicates the portion of food consumed by the animal that can be digested and absorbed in the gastrointestinal tract (Moss et al., 2017). With this information, it is possible to formulate more accurate diets to meet the requirements for maintenance and productive performance of broilers.

Total excreta collection method has been used as a reference for estimating the digestibility coefficients of nutrients in diets, and consists of strict control of the amount of foodingestedand thateliminated via excretaby the animal (A. G. M. Silva et al., 2018). However, high cost, long evaluation period, need for continuous labor, need for large sample size, extended time to adapt to experimental diet, and strict control of feed intake and excretion make indigestible marker method a feasible option for this purpose (Pombo, Valle, Bradi, \& Bueno, 2016). Digestibility indicators more reliably determine the initial and final period of excreta collection, obtaining more reliable results (Moss et al., 2017).

Therefore, the objective of this study was to evaluate three sources of acid insoluble ash (AIA) (celite, kaolin, and sand) as external markers to determine the apparent metabolizable energy of corn on a natural matter (AME) basis, dry matter digestibility coefficient (DMDC), and crude protein digestibility coefficient (CPDC) using the methods of total and partial excreta collection.

The experiment was carried out in the Poultry Section of the Campus Professora Cinobelina Elvas, at the Federal University of Piauí (UFPI), municipality of Bom Jesus, State of Piauí. A total of 210 male Ross broilers of 18 to 27 days of age, weighing an average of $510+26 \mathrm{~g}$ were used. The birds were initially housed in a conventional shed until 17 days of age, where they were given feed formulated to meet the nutritional requirements according to Rostagno et al. (2005).

On the 18th day, the birds were weighed and distributed into metabolic cages measuring $1 \times 1 \times 0.5 \mathrm{~m}$ in length, width, height, respectively, equipped with excreta collection trays, lined with plastic. The birds received ration and water ad libitum.

A reference diet (RD) based on corn and soybean meal was formulated to meet the nutritional requirements of the birds. A test diet with a $40 \%$ replacement of RD with corn was also prepared (Table 1). 
Table 1

Water already added with magnesium chloride $\left(\mathrm{MgCl}_{2}\right)$

\begin{tabular}{|c|c|}
\hline Ingredients & Inclusion level, \% \\
\hline Corn & 60.84 \\
\hline Soybean meal & 33.91 \\
\hline Soybean oil & 1.453 \\
\hline Salt & 0.434 \\
\hline DL-Methionine & 0.241 \\
\hline L-Lysine $\mathrm{HCl}$ & 0.190 \\
\hline Limestone & 0.823 \\
\hline Dicalcium phosphate & 1.777 \\
\hline Vitamin Supplement ${ }^{\mathrm{a}}$ & 0.100 \\
\hline Mineral Supplement ${ }^{\mathrm{b}}$ & 0.100 \\
\hline Choline chloride & 0.070 \\
\hline Antimicrobial $^{\mathrm{c}}$ & 0.005 \\
\hline Coccidiostatic $^{d}$ & 0.050 \\
\hline Total & 100.00 \\
\hline \multicolumn{2}{|l|}{ Nutritional Composition } \\
\hline Potassium, \% & 0.806 \\
\hline Chlorine, \% & 0.293 \\
\hline Linoleic acid, \% & 2.191 \\
\hline Apparent metabolizable energy, kcal/kg & 3.000 \\
\hline Crude Protein, \% & 20.79 \\
\hline Calcium, \% & 0.884 \\
\hline Available phosphorus, \% & 0.442 \\
\hline Digestible Methionine, \% & 0.533 \\
\hline Digestible Methionine + Digestible cystine, \% & 0.814 \\
\hline Digestible Lysine, \% & 1.146 \\
\hline Sodium, \% & 0.214 \\
\hline
\end{tabular}

a Vitamin supplement (composition per kg product): folic acid, 2,000 mg; pantothenic acid, $15 \mathrm{~g}$; niacin, $60 \mathrm{~g}$; biotin, 150 mg; vit. A, 13,000.00 IU; vit. $B_{1}, 4,000$ mg; vit. $B_{12^{\prime}} 20,000$ mcg; vit. $B_{2^{\prime}} 9,000$ mg; vit. $B_{6^{\prime}} 4,000$ mg; vit. $D_{3^{\prime}} 5.000 .000$ Ul; vit. E, 80.000 Ul; vit. $K_{3}, 4.000$ mg;

${ }^{\mathrm{b}}$ Mineral Supplement (composition per kg product): selenium, 300 mg; Mn, 100 g; Zn, 100 g; Fe, 40 g; Cu, 15 g; l, 1.000 mg;

c Zinc Bacitracin;

d Coxistac;

Treatments: celite, kaolin, and sand using total and partial collection;

Diets: D1- 99\% Reference diet + 1\% celite; D2- 59.4\% RD + 39.6 \% corn + 1\% celite; D3- 99\% Reference diet + 1\% kaolin; D4- 59.4\% RD + $39.6 \%$ corn + 1\% kaolin; D5- 99\% Reference diet + 1\% sand; D6- 59.4\% RD + $39.6 \%$ corn + 1\% sand. 
The treatments were distributed in a completely randomized design in a $2 \times 3$ factorial arrangement, to evaluate three sources of acid insoluble ash (celite, kaolin, and sand) as indicators and determine the apparent metabolizable energy of corn on a natural matter (AME) basis, dry matter digestibility coefficient (DMDC), and crude protein digestibility coefficient (CPDC) using two methods of excreta collection (total and partial). The treatments comprised six experimental diets (celite, kaolin, and sand using total and partial excreta collection), with five replications of seven birds each:

D1: $99 \%$ Reference diet $+1 \%$ celite;

D2: $59.4 \%$ RD + $39.6 \%$ corn $+1 \%$ celite;

D3: 99\% Reference diet + 1\% kaolin;

D4: $59.4 \%$ RD + 39.6 \% corn + 1\% kaolin;

D5: $99 \%$ Reference diet + $1 \%$ sand;

D6: $59.4 \%$ RD + $39.6 \%$ corn $+1 \%$ sand .

Birds of 18 to 27 days of age were adapted to the experimental diet for four days, and excreta were collected for five days. The diets were weighed and $1 \%$ ferric oxide was added on the first and last day of collection.

The excreta were collected twice a day, packed in plastic bags, identified, weighed, and stored in a freezer at $-5^{\circ} \mathrm{C}$. At the end of the experimental period, the amount of feed consumed and excreta produced were determined. Feces were thawed and homogenized, and approximately $10 \%$ was taken (partial collection) and dried in a forced ventilation oven at $55^{\circ} \mathrm{C}$ for 72 hours. Thereafter, excreta and feed samples were ground and sent to the laboratory for determination of dry matter, crude energy, and nitrogen contents according to D. J. Silva and Queiroz (2002), and insoluble acid ash using a methodology adapted from Carvalho et al. (2013). The results obtained were used to calculate the apparent metabolizable energy (AME) values, according to the formulas described by Sakomura and Rostagno (2016).

All analyzed variables were checked for the presence of outliers, and assumptions of normality of student errors (Cramer-vonMisses test) and homogeneity of variances (levene test) were tested. After verifying the non-violation of the assumptions, the data were subjected to analysis of variance using the GLM procedure of the statistical program SAS (1996). To compare the means, the SNK test was used with $95 \%$ significance.

There were significant interactions $(P \leq 0.05)$ for all variables investigated (Table 2). It was observed that the values of $A M E$ and DMDC of corn using kaolin were similar in the two methods of collection. The values of CPDC using kaolin and celite were also similar. However, the AME and CPDC of corn using sand with partial collection method were underestimated by 17.70 and $15.53 \%$, respectively compared to those in total collection method. The AME values of corn using celite were significantly different in both collection methods. Similarly, DMDC using celite and sand were significantly different. It was observed that the DMDC using celite and sand provided significantly lower values of 4.67 and $5.15 \%$, respectively, and the AME using celite obtained by partial collection was $2.86 \%$ lower than that obtained by total collection.

Some authors reported that acid insoluble ash (AIA) may overestimate the digestibility and energy values of feed ingredients (Coca-Sinova et al., 2011). This 
may occur owing to incomplete solubilization of soluble minerals in hydrochloric acid, such as calcium and phosphorus in animal feces, overestimating the AIA content in excreta (Zanatta et al., 2013).

Researchers are yet to find a substance with a perfect indicator feature.
However, Carvalho et al. (2013) showed that partial collection with marker method is comparable to the standard procedure of total collection of excreta, indicating that acid insoluble ash (AIA) can be used as a marker to predict the AME and digestibility coefficients of ingredients, as they present similar results.

\section{Table 1}

Water already added with magnesium chloride $\left(\mathrm{MgCl}_{2}\right)$

\begin{tabular}{|c|c|c|c|c|c|c|c|c|}
\hline \multirow{2}{*}{ Variables } & \multirow{2}{*}{ Marker } & \multicolumn{2}{|c|}{ Collection } & \multirow{2}{*}{ Mean } & Collection & Marker & $\mathrm{Cb} \times \mathrm{Mc}$ & $\mathrm{CVa}$ \\
\hline & & Total & Partial & & \multicolumn{3}{|c|}{ Probability } & (\%) \\
\hline \multirow{6}{*}{$\begin{array}{c}\mathrm{AME}_{1} \\
\mathrm{kcal} / \mathrm{kg}\end{array}$} & Celite & 3.49Aa & $3.28 \mathrm{Ab}$ & 3.38 & & & & \\
\hline & Kaolin & 3.68Aa & 3.75Aa & 3.72 & & & & \\
\hline & Sand & 3.56Aa & $2.93 \mathrm{BC}$ & 3.24 & $<0.0001$ & $<0.0001$ & $<0.0001$ & 3.79 \\
\hline & Mean & 3.58 & 3.33 & & & & & \\
\hline & Celite & 81.59Aa & 77.78Ab & 79.68 & & & & \\
\hline & Kaolin & 82.36Aa & 84.72Aa & 83.54 & & & & \\
\hline \multirow[t]{4}{*}{ DMDC, \% } & Sand & 82.95Aa & 78.68Ab & 80.81 & 0.0835 & 0.0192 & 0.0296 & 3.56 \\
\hline & Mean & 82.30 & 80.39 & & & & & \\
\hline & Celite & 67.34Aa & $68.06 \mathrm{Aa}$ & 67.70 & & & & \\
\hline & Kaolin & $67.95 \mathrm{Aa}$ & 70.77Aa & 69.36 & & & & \\
\hline \multirow[t]{2}{*}{ CPDC, \% } & Sand & $72.20 \mathrm{Aa}$ & $60.99 \mathrm{Bb}$ & 66.60 & 0.2334 & 0.5703 & 0.0196 & 7.35 \\
\hline & Mean & 67.79 & 65.79 & & & & & \\
\hline
\end{tabular}

Acid insoluble ash could be used as an internal marker to calculate the digestibility of a diet precisely, and the method could be used as an alternative to total collection method in many animals (Figueiredo et al., 2019; Papadomichelakis \& Fegeros, 2020). However, Prawirodigdo, Gannon, Leury and
Dunshea (2021) demonstrated that the basal diet and choice of indigestible marker can substantially influence the determination of apparent total tract digestibility and that the use of AIA as an indigestible marker varies with species of animal used. 
To determine EMA, DMDC, and CPDC in broilers, it is efficient to use celiteTM and kaolin as markers with partial collection of excreta. Sand should not be used with partial collection method, because the values of AME and CPDC were lower compared with the values obtained by total excreta collection method.

\section{References}

Carvalho, G. B., Dourado, L. R. B., Lopes, J. B., Ferreira, A. H. C., Ribeiro, M. N., Silva, S. R. G.,... Silva, F. E. S. (2013). Métodos de análise da cinza insolúvel em ácido utilizada como indicador na determinação da energia metabolizável do milho para aves. Revista Brasileira de Saúde e Produção Animal, 14(1), 43-53. doi: 10.1590/S1519-99402013000100005

Coca-Sinova, A., Mateos, G. G., GonzalezAlvarado, J. M., Centeno, C., Lazaro, R., \& Jimenez-Moreno, E. (2011). Comparative study of two analytical procedures for the determination of acid insoluble ash for evaluation of nutrient retention in broilers. Spanish Journal of Agricultural Research, 9(3), 761-768. doi: 10.5424/ sjar/20110903-439-10

Figueiredo, M. R., Saliba, E. O. S., Barbosa, G. S. S. C., Silva, F. A., Nunes, A. N., Silva, C. R. M., \& Moreira, G. R. (2019). Use of indigestible markers to estimate the apparent dry matter digestibility of diets containing a cocoa by-product, Semina: Ciências Agrárias, 40(6), 2771-2782. doi: 10.5433/1679-0359. 2019v40n6p2771

Melo, C. C. V., Alvarenga, R. R., Santos, L. M., Oliveira, D. M., Lago, A. A., Oliveira, E. C.,...
Zangeronimo, M. G. (2014). Influência de diferentes intervalos de coleta de excretas sobre o valor energético e de nutrientes metabolizáveis de alimentos para aves. Acta Tecnológica, 9(1), 27-32. doi: 10.35818/acta.v9i2. 293

Moss, P. C. B., Rezende, A. S. C., Saliba, E. O. S., Lana, A. M. Q., Moura, R. S., Cassou, F.,... Alves, G. E. S. (2017). Validation of Nanolipe ${ }^{\circledR}$ as method to assess the apparent digestibility of nutrients on horses. Arquivos Brasileiro de Medicina Veterinária e Zootecnia, 69(3), 687-694. doi: 10.1590/1678-4162-8270

Papadomichelakis, G., \& Fegeros, K. (2020). Reliability of acid-insoluble ash as internal marker for the measurement of digestibility in rabbits. World Rabbit Science, 28(1), 1-12. doi: 10.4995/wrs.20 20.12216

Pombo, G., Valle, T. D., Bradi, R. A., \& Bueno, I. C. S. (2016). Acurácia, precisão e robustez de indicadores internos para predição da digestibilidade aparente total de matéria seca em equinos. Arquivo Brasileiro de Medicina Veterinária e Zootecnia, 68(3), 769-775. doi: 10.1590/1678-4162-8441

Prawirodigdo, S., Gannon, N. J., Leury, B. J., \& Dunshea, F. R. (2021). Acid-insoluble ash is a better indigestible marker than chromic oxide to measure apparent total tract digestibility in pigs. Animal Nutrition, 7(1), 64-71. doi: 10.1016/j.aninu.2020.07.003

Rostagno, H. S., Albino, L. F. T., Donzele, J. L., Gomes, P. C., Oliveira, R. F., Lopes, D. C.,... Barreto, S. L. T. (2005). Tabelas brasileiras para aves e suínos: composição de alimentos e exigências nutricionais (2a ed.). Viçosa, MG: UFV. 
Sakomura, N. K., \& Rostagno, H. S. (2016). Métodos de pesquisa em nutrição de monogástricos (2nd ed.). Jaboticabal: FUNEP.

Silva, A. G. M., Borges, I., Neiva, J. N. M., Rodriguez, N. M., Saliba, E. O. S., Morais, S. A.,... Valle, R. C. A. (2018). Avaliação do lipe $^{\circledR}$ como indicador externo de digestibilidade em ovinos recebendo dietas com torta de babaçu. Revista Brasileira de Nutrição Animal, 12(1), 39-44. Recovered from http://www. nutricaoanimal.ufc.br/seer/index.php/ higieneanimal/article/view/469/2349
Silva, D. J., \& Queiroz A. C. (2002). Análise de alimentos: métodos químicos e biológicos (3nd ed.). Viçosa, MG: UFV.

SAS Institute Inc. (1996) SAS/STAT User's Guide, Version 6, Fourth Edition, Vol. 2. SAS Proprietary Software Release 6.12. SAS Institute, Inc., Cary, NC.

Zanatta, C. P., Gabeloni, L. R., Félix, A. P., Brito, C. B. M., Oliveira, S. G., \& Maiorka, A. (2013). Metodologias para determinação da digestibilidade de dietas contendo fontes proteicas vegetal ou animal em cães. Ciência Rural, 43(4), 696-701. doi: 10.1590/S0103-84782013005000024 